\title{
Crisis, what crisis? The media: business and journalism in times of crisis
}

\author{
Rosario de Mateo*, Laura Bergés**, Anna Garnatxe ${ }^{* * *}$, \\ Department of Media, Communication and Culture, \\ Universitat Autònoma de Barcelona \\ *Rosario.demateo@uab.cat, ** Laura.berges@uab.cat, ${ }^{* * *}$ Anna.garnatxe@uab.cat
}

Contribution to the tripleC-special issue "Capitalist Crisis, Communication \& Culture", edited by Christian Fuchs, Matthias Schafranek, David Hakken, Marcus Breen

\begin{abstract}
The global financial and economic crisis is often used to justify a crisis of media and journalism: lower advertising, collapses in the share price, falls in consumption, more unemployment. But is this just a business crisis, or is it also a crisis in journalism and its role in democratic societies? In this case, is the journalism crisis attributable to the economic crisis or, rather, was it forged during the years of high profitability and high salaries in the mass media? These two sides of the crisis, in media industry and in journalism, are addressed in this article, which explores the evolution of mainly Spanish media in the years before the crisis. However, in order to understand how they reached the current situation, political and economic transformations in what has been called the Information Society and neoliberal globalization must be addressed.
\end{abstract}

Keywords: crisis, journalism, media economics, Information Society

\section{Introduction}

The global financial and economic crisis is often used to justify a crisis of media and journalism. Data listed below attests to this crisis but, as discussed in this paper, is not sufficient to explain the whole problem. We must go further.

Infoadex $(2009,2010)$ scored a drop in advertising expenditure in the Spanish media of $21 \%$ in 2009 , surpassing the $11.1 \%$ decline in 2008 . The printed press is once again the media with the greatest decrease in advertising expenditure, $-22 \%$ in 2009 for newspapers and $-34 \%$ on Sundays, adding to a decline of $20 \%$ and $22 \%$ in 2008 . Television also has poorer figures than the already negative ones for 2008: in 2009 it lost $23 \%$ of advertising investment, which had fallen by $11.1 \%$ the previous year, with local channels losing three quarters of their sales last year $(-76 \%)$. The crisis also affects Internet advertising, where expenditure in 2008 "only" rose by $16 \%$ (compared with growth of $55 \%$ in 2007), and in 2009 grew only $7 \%$.

The Union of Journalists of Catalonia recorded, in April 2009, more than 3,500 dismissals of journalists in Spain from 2008 to that date, located in large multinational corporations, in major Spanish publishing groups, in the local press and local television and in financial newspapers. From the beginning of 2008 to the end of 2009, the share price of the large Spanish media groups on the market fell by $26.25 \%$ for Antena 3 TV, $72.10 \%$ for Prisa and $47.55 \%$ for Telecinco ${ }^{1}$ (Sogecable's trading was suspended after it was absorbed by its largest shareholder, Prisa, in 2008).

Several media closed their doors between 2008 and 2009: Metro stopped publishing its free paper in Spain; Planeta reduced the number of local editions of another, $A D N$; Prisa started closing its local television network Localia TV; Vocento also halted its expansion into that market with Urbe

http://www.finanzas.com/cotizacion/historico-ANTENA-3-TV-mercadocontinuo.htm?3, http://www.bolsa.es/cotizacionvalor/antena-3-tv/, http://www.bolsa.es/cotizacion-valor/prisal, http://www.bolsa.es/cotizacion-valor/telecincol . 
$T V$; losses forced national broadcasters to merge; and several new private regional DTT channels never went on air.

Less advertising, collapses in the share price, falls in consumption, more unemployment make it is clear that the economic crisis has hit the media industry. But is this just a business crisis, or is it also a crisis for journalism and its role in democratic societies? And, if that is the case, is the journalism crisis attributable to the economic crisis or, rather, was it forged during the years of high profitability and high salaries in the mass media? These two sides of the crisis, in the media industry and in journalism, are addressed by this article, which explores the evolution of mainly Spanish media in the years before the crisis. We analyse the evolution of media's supply and demand, its effects on the results of different types of companies, and the transformations in their business models. From that we move to analyse the crises in journalism, where the economic interests overhang the general interests. Changes in media industries have led almost all media to a greater or lesser degree of dependence, with more trivialization of news, precarious employment and so precarious journalism.

However, in order to understand how they reached the current situation, the political and economic transformations of recent decades must be addressed -transformations that occurred as solutions for the previous crisis in the seventies, in what has been called the Information Society and neoliberal globalization.

\section{Crisis of the Information Society}

The subprime mortgages of September 2007 were the first signs of the global financial crisis, which would later be extended universally from September 2008 following the collapse of one of the world's largest banks, Lehman Brothers. Somewhat later, this crisis hit the productive economy, causing fear and uncertainty in all sectors of activity, both in terms of supply and demand.

But the current financial and economic crisis, which also affects the media, does not seem to be a short-term crisis like those of 1962,1987, 1993 and 2001. Instead, it seems to be a structural crisis of the capitalist economic and social system. Therefore, partial and often disjointed solutions would not be sufficient. Instead there is a need for structural measures to change the model of production and exchange created at the beginning of the nineties and known as the Information Society.

The industrial, monetary and oil crisis of the late sixties and early seventies marked the beginning of the end of the growth and exchange model that appeared after World War II and was led by the United States. The saturation of existing markets due to overproduction and lower productivity reduced growth in traditional industries. As a result, the profitability of the industrial sector declined, prompting heavy debt for companies and countries that were unable to find their own funds to make investments in other activities, mainly in the service sector, profitable. This was one of the main causes of the breakdown of the international monetary system created in 1944 in Bretton Woods, which was substituted by a widespread floating currency exchange rate. The 1973 oil crisis ended the timid economic recovery that seemed to have dawned, and the world economy changed from a credit system with excess liquidity to another one with a shortage of liquidity (IASC, 1983, 1984).

From that moment, the grounds were prepared for possible changes in the production and exchange processes. Given the choice between a reform seeking a more sustainable economy and a reform whose main objective was still maximum profit, the second option was chosen, and driven by the Thatcher and Reagan governments, international economic organizations, and multinational companies. Thus began what some have called the third industrial revolution, or what is now almost universally known as the Information Society.

The proposal for this new growth model was specified in the US, in 1991, through the HighPerformance Computing Act, which led to the Global Information Infrastructure (GII) proposed by Vice President Al Gore in 1994, and which was renamed by the European Commission as the Information Society (EC, 1994). Both projects focus only on economic aspects, not social or political ones. 
In those projects, economic growth and trade have their main base in the service sector, where information and communication technologies (ICT) play a key role. The implementation of ICT will also be extended to the primary and secondary sectors of economic activity, for greater productivity in a global market characterized by liberalisation, deregulation and international competition and, consequently, privatisation of public enterprises, especially those in the service sector, including those of the audiovisual industry. Furthermore, this model is based on the existence of a flexible regulatory framework that will assist technological convergence in order to increase the productivity of businesses, enabling them to accumulate enough capital to be able to act in a globalised market. It is also based on the role of the market, whose rules command the operation of different industries and companies, with the financial market being the most extreme case, as it is fully globalised and lacks any regulation.

Thus, the principles governing the Information Society are certainly not neutral because they are targeted mainly at economic restructuring, and do not cater for their social impact, which is promoting the gradual dismantlement of the previous development model known as the welfare state.

The countries that are most deeply involved in this process are world's most developed countries, which have clear competitive advantages in this new economic order in comparison with other countries that can only act on the change in tow of the rules issued by the US and the EU, and its member states, also supported by regional economic organisations such as the Organisation for Economic Cooperation and Development (OECD), and international economic institutions such as the International Monetary Fund (IMF), the World Bank and the World Trade Organization. And, as a fundamental lobby throughout this process, multinational or transnational companies.

In that sense the last round of negotiations under the General Agreement on Tariffs and Trade (GATT became the World Trade Organization in 1995) was significant as it led to the dominance in the global economy of deregulation, liberalisation and global competitiveness of services and to the extension of intellectual property and derived economic rights, with the General Agreement on Trade in Services (GATS) and the Trade-Related aspects of Intellectual Property Rights (TRIPS) being signed in 1994. The GATS included, but without any agreement, telecommunications, computer, audiovisual and other services. The United States succeeded in introducing these controversial issues, especially the audiovisual one. It was just a matter of time before there would be more agreements, but the important thing was, despite the cultural exception achieved by the European Union largely at the behest of France, that the cultural and, more precisely, the communication industry, was incorporated in the dominant industrial status.

On the one hand, the convergence of telecommunications, computers and audiovisuals created exaggerated expectations by many analysts because it seemed to generate the possibility of new businesses whose profitability, in some cases, is still uncertain and, in other cases, has been a failure, as happened in the late nineties, with the stock market debacle that did away with most Internet-based companies (de Mateo, 2006). On the other hand, this growth model is based on the service sector which, since the end of World War II, has taken the highest percentage of the active population and contributed most to the growth of the Gross Domestic Product (GDP). The problem is that the service sector depends on economic evolution and the income of the demandants. And, in times of economic crisis like the present, consumption is reduced, since it depends on surplus income, which questions the growth model of the Information Society based on the service sector, which has employed an increasingly less necessary active population.

The Information Society, like before, continued to pursue the maximum profit, which has led to a continuous and increasing waste of resources and to the pursuit of greater productivity to save those resources. For labour, it marked the beginning of precarious contracts, with rising unemployment rates, and decreasing or stagnant wages, which put increasing pressure on the living standards of many people.

But these limitations of the growth model of the Information Society were masked by a liberalized financial system, in which, since the early nineties, the financial sector has been the connecting element between goods and services, consumption, income and debt. Thus, the rapid exit from the crisis of 1993 and 2001 was due to the indebtedness of households and businesses to con- 
sume and invest. In 2000, that debt was massive and increasing, due to the collapse of interest rates, enabling economic growth based on real estate and financial speculation and mass consumption by individuals and families. From 2004 to 2007, growth was based on credit that financial institutions covered with funds from other financial institutions. This lasted until September 2007, when what was known as the subprime mortgage crisis emerged, which meant the excessive accumulation by financial institutions of a debt negotiated to infinity.

This excessive growth, with periods of welfare in developed countries, was at the expense of unsustainable spending, and often wastage, of resources that now, in 2010, seems to be unsustainable because such stability has been forgotten. At the same time, one of the elements essential to the functioning of democracy and the economy has been lost, namely trust.

In Spain, the financial and economic crisis, and that of the media will be long and complicated as the growth model is based primarily on low added value, low productivity and labour-intensive industries: construction, automobiles and tourism. That is why in the current economic crisis the unemployment rate is higher than in other countries. The unemployment rate in Spain was 8.5 in 2006 and 8.3 in 2007; and grew rapidly to reach 11.3 in 2008; and 18.0 in 2008. Moreover, it is also a highly externally dependent economy, in terms of both energy and capital.

With the prospect of more than two decades, it can be said that the media industry, and mainly its audiovisual industry, followed a similar development, but later on, to other industries in the process of structural changes to the global economy that initiated in the late sixties. The dominant media companies have also been immersed in processes of growth accompanied by liberalisation, privatisation, concentration and internationalisation in the same way as other industries (Harvey, 2005; Arriola and Guerrero, 2000). These business dynamics have an overt influence on the social communication markets.

Considered in such a way, the media, like companies from any other economic activity, suffer from a global economic and financial crisis that has left no arguments for the advocates of neoliberalism. Its choice of unlimited growth, based mainly on the service sector, to overcome the crisis of the seventies seems to have reached the point of no return. The problems with overproduction, sub liquidity, debt, monetary, financial and energy crises of the seventies have reappeared from 2007 onwards. The solution is not easy, since the current economic and financial crisis does not seem cyclical but rather is a structural crisis of the capitalist system that has to cope with its development in a world of limited resources.

\section{The crisis of media companies}

In this changing context, the media industry will be subject to a transformation combining new technological opportunities, greater availability of financial resources, changes in advertisers' expenditure strategies, reassignments in audience markets, and changes in corporate governance.

\subsection{Crisis of overproduction}

The media industry crisis can be characterized as a crisis of overproduction, after two decades of expanding communication markets. The excess production of consumer goods which, among other factors, led to the crisis of the seventies would therefore affect the production of services that during the nineties absorbed surplus capital from other activities, leading to a crises of overaccumulation (Bellamy Foster and Magdoff, 2009). Ever since the eighties there has been continued growth in the supply of media, either by the expansion of the supply of traditional media or by the emergence of new media (see Table 1). 


\begin{tabular}{|l|c|c|}
\hline & $\mathbf{1 9 8 9}$ & $\mathbf{2 0 0 9}$ \\
\hline Television & 4 & 28 \\
National free to air channels & 1 & 108 \\
Pay-tv channels & 8 & 77 \\
Regional channels & $100-200^{*}$ & 1,117 \\
Local channels & & \\
\hline Radio & $389^{* *}$ & 6,186 \\
FM stations & 3 & 5 \\
General programming national networks & 8 & 27 \\
Regional public networks & 2 & 5 \\
\hline Daily press & 2 & 2 \\
National press published in Madrid & 4 & 7 \\
National press published in Barcelona & 2 & 5 \\
Sport news & 70 & 90 \\
Financial news & - & 4 \\
Regional and local press & & 167 terabytes \\
Freesheets for big cities & & $\geq 21.39$ billion \\
\hline Internet & - & websites \\
Information indexed by the major search & & 350 \\
engines & - & \\
Digital media controlled by OJD & & \\
\hline
\end{tabular}

Table 1: Media supply in Spain: 20 years of growth ${ }^{2}$

In Spain, there were 2 national channels and 8 regional channels in 1988, while in 2009 there were more than 1,350 channels, in addition to the growing online audiovisual offer. There has been an increase both in the public sector, with new regional, local and national channels, and especially in the private commercial sector, most favoured by new broadcasting technologies (cable, satellite, DTT, IPTV).

As for the printed press, after the restructuring of the market in the eighties following the fall of the dictatorship, and going into the nineties, two new national general interest newspapers were born- El Mundo, in 1994, and La Razón, in 1998 - and in the 2000s, another pay-newspaper appeared - Publico, in 2007 - along with four new free nationally circulated newspapers - 20 minutos, in 2000; Metro, in 2001; Qué!, in 2005; and ADN, in 2006. The Office for the Control of Circulation (Spanish acronym OJD) controlled, in 2009, 106 dailies, compared to a total of 80 newspapers in 1989 , and also with a greater offer of financial, sports and local newspapers.

The number of radio stations and networks has also been increasing steadily since the approval of the Technical Plan of 1989 (Royal Decree 169/1989). With this plan, the number of frequencies for the commercial exploitation the FM wavelength grew from 389 to 758 . And, in 2006, a new technical plan was approved (Royal Decree 964/2006) that licensed 866 new frequencies to private radio, which meant an increase of $83.4 \%$; and 235 for public radio, with a $48.7 \%$ increase on the previous situation.

The emergence of new electronic media has been added to the increasing supply of traditional media, opening the door to a market for wide content in which media companies compete with governments, other companies and institutions, citizens and social organisations to offer cultural, informative, advertising and entertainment content directly to users. In addition to websites, social

\footnotetext{
${ }^{2}$ Source: the author is using data from TDT and Impulsa European Audiovisual Observatory 2009, for television; Amoedo 2008 for radio stations, http://www.worldwidewebsize.com/ for internet, local tv *: estimates for 1991, Guimerà, 2006. * Does not include publicly owned stations.
} 
networks and blogs are other public spaces not only for personal and group communication, but that sometimes also act as social mass media (for example, Twitter and Iran). The major search engines offer access to at least 21.39 billion websites, corresponding to the visible web, which occupies 167 TB of information. There is also the invisible or deep web that multiplies the figures, with an amount of information calculated at $91,000 \mathrm{~TB}$. Although this information is inaccessible to main search engines, technologies to expand the coverage of the search tools are developing to provide greater coverage of the entire web.

Among this vast amount of information scattered across the net and accessible from anywhere in the world, national rates of Internet use can delimit a smaller supply of digital media and comparable sites. In Spain, for example, the OJD controls 350 sites, including online newspapers and television, and a few radio stations, but also some corporate websites, political parties, classified advertising sites and thematic portals, among others.

Thus, in the nineties and 2000s, there was a significant increase in the supply of media, driven mostly by the same traditional media companies that pursued multimedia, horizontal, vertical and conglomerate growth strategies. The growth was also driven by the entry of new players, competing with media companies, especially in the new digital markets, where these companies converge, compete and cooperate with telecommunications and ICT multinationals as well as with companies, institutions and citizens that also offer content through digital networks.

\subsection{Redistribution of advertising expenditure: entertainment and personalisation beat information for large audiences}

The increase in the number of media, services and communication technologies has led to a major restructuring of advertising markets, cushioned by a shift of total advertising expenditure in a context of economic growth, interrupted by short-term crises in 1993 and 2001. The development of below-the-line advertising should be noted as the major change in advertising markets, thanks to the liberalisation and development of telecommunications and ICT, and through a progressive "colonization" of new spaces / times as carriers of commercial messages, which include facades, public and private vehicles, sport and cultural events and centres, among others. According to Infoadex studies, in Spain below-the-line advertising ${ }^{3}$ represented $20 \%$ of total advertising expenditure in 1980; it grew rapidly through 1989-92 to reach 53\%, surpassing media for first time in 1991. From there, Infoadex data allocates just over half of the investment in below-the-line advertising (between $51 / 54 \%$ of advertising expenditure in the 1991-2008 periods). Other sources calculate the weight of above-the-line advertising to be below $25 \%$ of the total expenditure by companies on advertising services (Bergés et al., 2006, with input-output tables INE-Idescat).

In any case, from the nineties on, in a context of saturated markets, companies have increased their advertising efforts and sought methods for more personalised promotion to create a more direct and enduring relationship with consumers. This translates into significant growth in telephone advertising, mailing and brochures, first, and in the 2000s, the use of email, social networks and other forms of advertising that seek personalisation through new digital ICTs (behaviouralmarketing, search engines and social network marketing, viral marketing). There has also been a major increase in expenditure on in-store advertising and signage, sponsorship and, although with less weight, advertising linked to games.

Thus, traditional media have to face increasing competition from other media in attracting advertising revenue. This will determine their strategies, including the definition of products, which must be more attentive to the interests of advertisers and major advertising companies that concentrate the greatest purchasing power. The high presence of sport in the supply of media can be explained

\footnotetext{
${ }^{3}$ According to Infoadex, below-the-line advertising includes: personalised mailing, brochures and mail, marketing by phone, promotional gifts, signage, exhibitions and fairs, sponsorship and social marketing, sport sponsorship, business publications, directories and yearbooks, promotional games, rewards or loyalty cards, and mobile marketing. Above-the-line advertising includes: daily press, Sunday supplements and magazines, radio, television, cinema, internet, and outdoor advertising.
} 
by its high advertising value: it admits sponsorships that subsequently gain notoriety thanks to the presence of sport in the media, while also serving as a vehicle for other advertisers.

Moreover, and as in the above-the-line advertising market, the introduction, in the nineties, and subsequent expansion of the private television market (with new free-to-air channels in 2003/05, and more public channels also financed by advertising) has resulted in a greater concentration of media advertising expenditure in television at the expense of newspapers and magazines, the media that has lost the biggest market share. The press has also suffered from competition from outdoor advertising (especially since 2001) and, as from 2006, internet. In Spain, the press' share of the advertising pie has been in decline since the late eighties: $30 \%$ in 1980 , and $36 \%$ in 1988 ; $30.4 \%$ in $1991 ; 29.1 \%$ in $2001 ; 21.2 \%$ in 2008 . Magazines also lost much of their share after the introduction of private television (Figure 1).

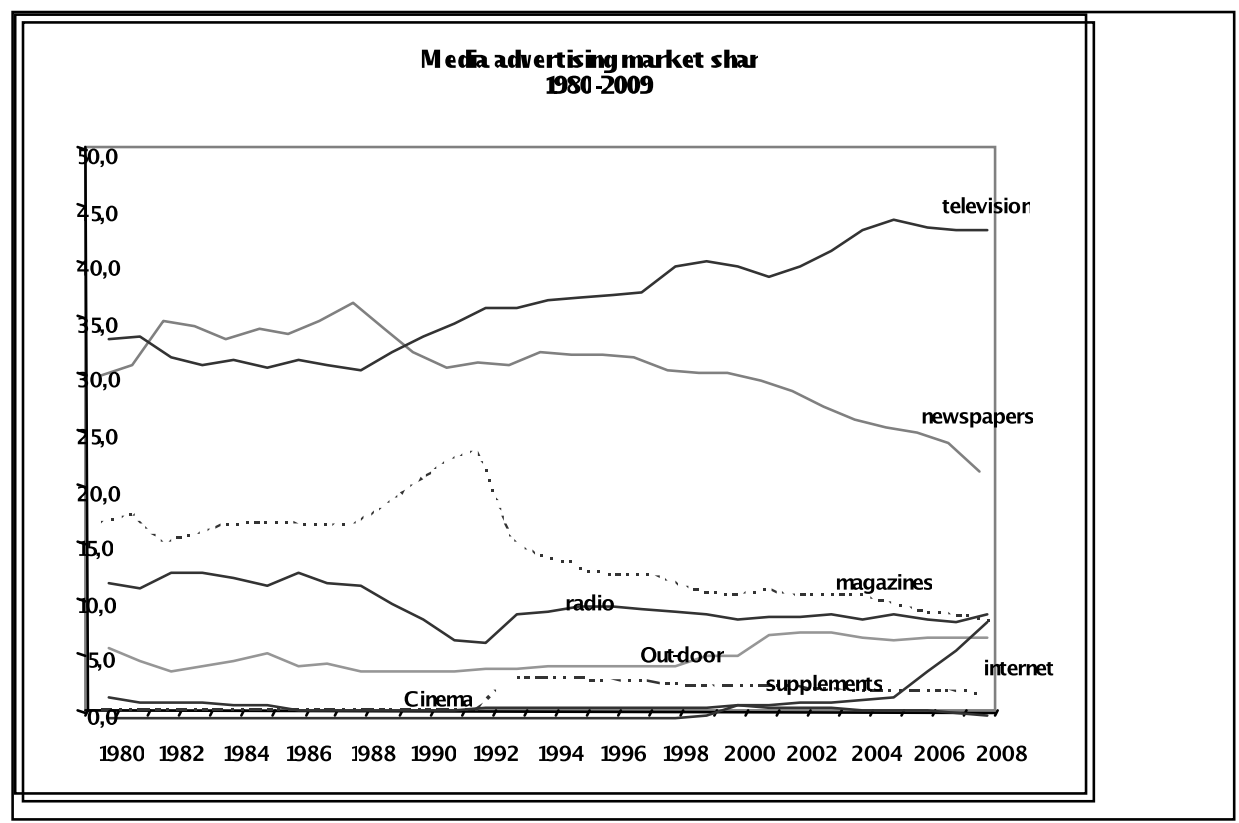

Figure 1: Media advertising market share ${ }^{4}$

As the supply of advertising media has changed (more promotional vehicles), so has the demand for advertising. The changes in this demand, and particularly above-the-line advertising expenditure, have been linked to the evolution of the economy; although the relationship between GDP and advertising expenditure is not strictly parallel (Figure 2). The economic crisis of the early eighties was cushioned by the development of media and advertising systems after the dictatorship, leading to growth rates in advertising expenditure in Spain of over $20-30 \%$ throughout the decade (current rates), which was considerably above current GDP growth rates.

In the nineties, advertising expenditure grew at lower rates than the variation in economic growth, except in 1991-1992, with the expansion of the advertising market due to the introduction of private television, and in 1998-1999, when advertising demand grew more than GDP, driven by the major promotional effort by the sectors subject to liberalization and privatization (telecoms Telefonica and Retevisión / Auna appeared among the main advertisers just after its privatization was completed). The economic growth after the 2001 corresponded with similar growth in advertising expenditure, which plummeted in 2008-2009, with the traditional media being the most sensitive to the crisis.

\footnotetext{
${ }^{4}$ Source: the author using Infoadex data and estimates for 1989-1991
} 
Evolution of ad spending relative to GDP (1981-2007, current)

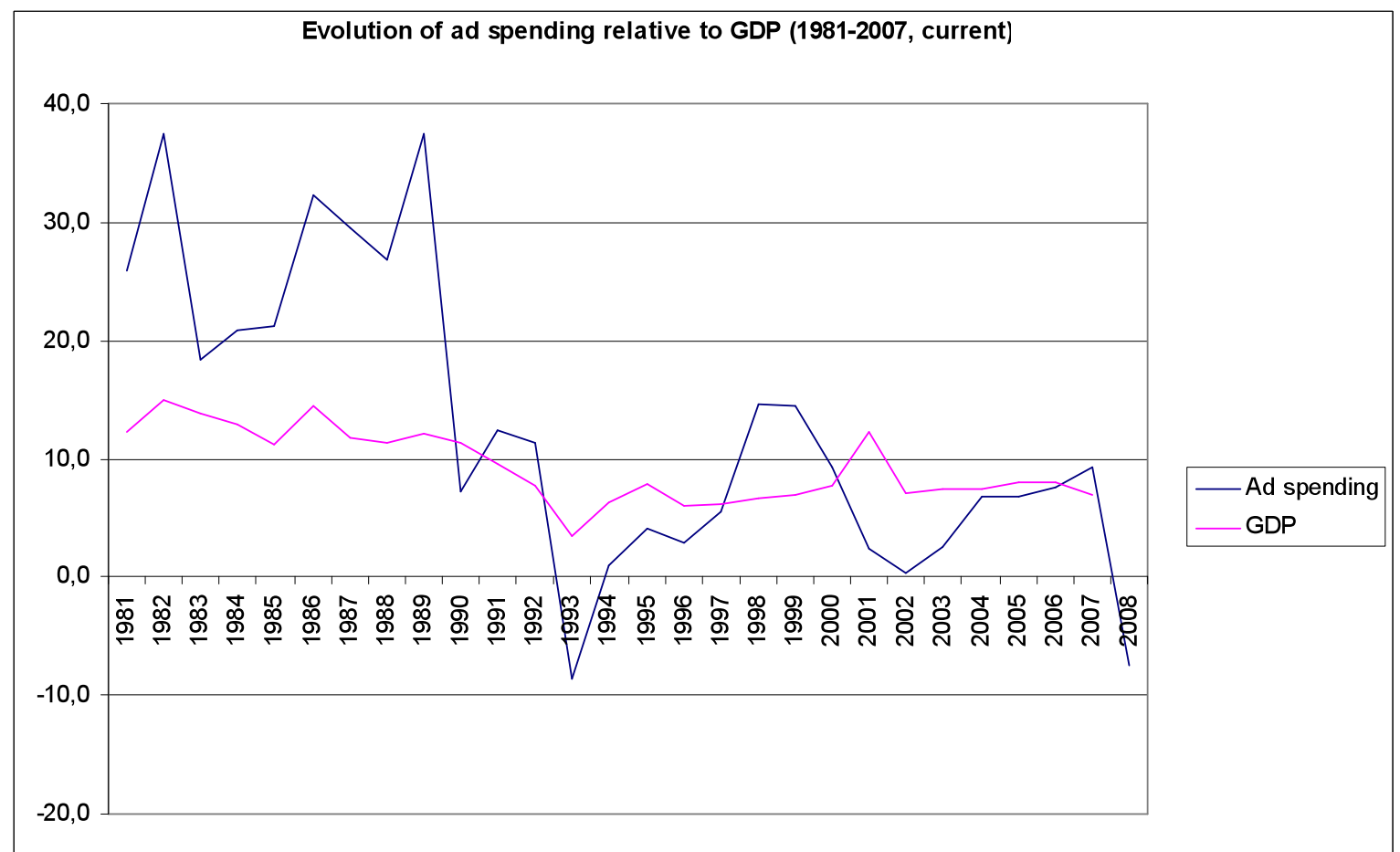

Figure 2: Evolution of advertising expenditure relative to GDP (1981-2007, current values)

The decrease in advertising expenditure was greater than the fall in GDP, due to the weight in advertising markets of some of the sectors that were most affected by the crisis (automobiles, finance, culture and media, construction, public sector) and the high concentration of expenditure by a few companies. These major advertisers are cutting investment by migrating to digital media at a time when the media mix is being restructured (WARC, 2009, 2010).

It should be noted that $90 \%$ of the investment controlled by Infoadex corresponds to $20 \%$ of all advertisers: major brands with multimedia advertising expenditure, both in traditional media and in new media, that ultimately also affects the former, for example, through sponsorship or outdoor advertising. On the contrary, more than half of the advertisers controlled by Infoadex only spend on newspapers (Infoadex, 2009), which have, therefore, an important position in the market for small and medium advertisers.

\subsection{Audience redistribution}

The restructuring of the media industry and markets also includes increased media consumption and a redistribution of audiences. Over the last decade (1999-2009), newspapers, radio and the Internet, have increased their penetration, while the audiences of supplements, magazines, television and film have been reduced (Figure 3).

\footnotetext{
${ }^{5}$ Source: the author using data from Infoadex and INE
} 


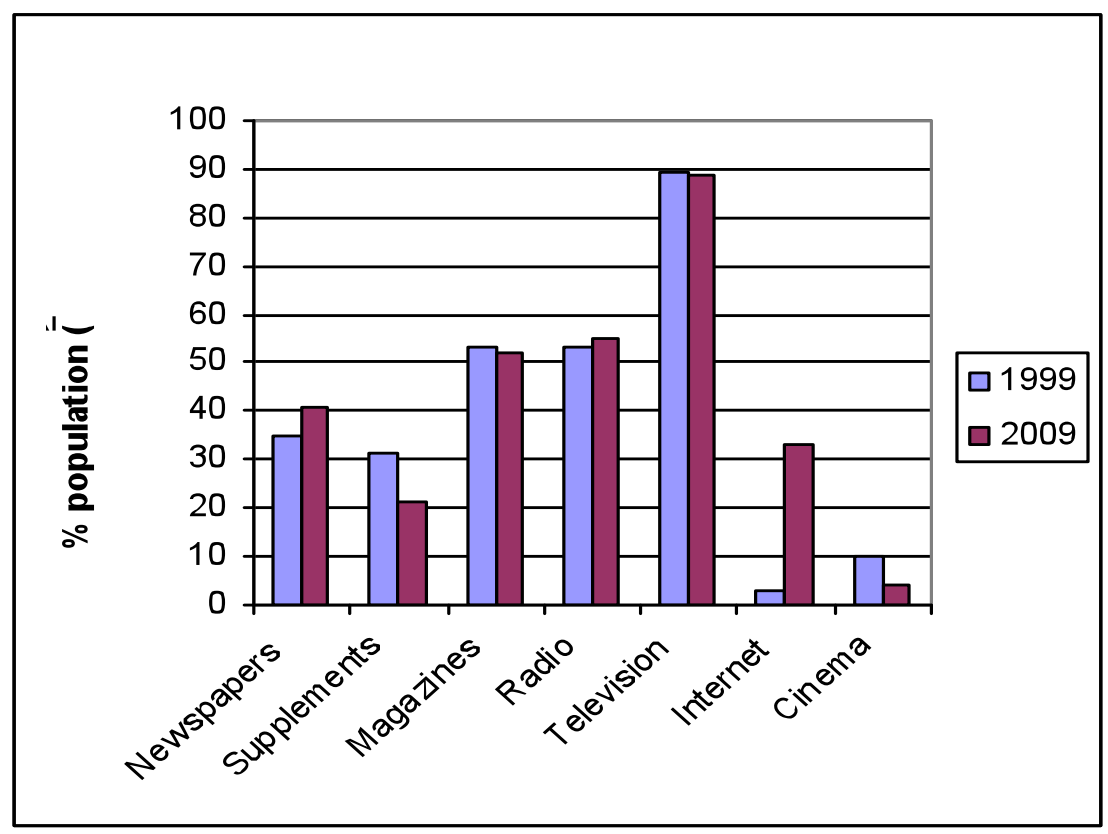

Figure 3: Use of media in Spain, 1999-2009 (EGM, 2010). Press, Radio, Television: users/day. Internet: users/yesterday. Supplements and cinema: users/week. Magazines: users/publishing period.

In the late nineties, the Spanish rate of daily press readers fell to a minimum of $35.2 \%$ in 1999 , before rising again from 2003 to 2008 (42.1\%). This increase should mainly be attributed to the free sheets, which in nine years has reached about six million readers. Sports and general interest national newspapers also gained readers, with a $45 \%$ growth in reading rates. Less importantly, the financial press also increased its readership over those five years. In contrast, the evolution of the regional press was more variable, but with a downward trend (Table 2).

\begin{tabular}{|l|r|r|r|c|}
\hline & Oct 2000- & $\begin{array}{r}\text { Oct. 2008 } \\
\text {-May 2009 }\end{array}$ & $\begin{array}{r}\text { Growth } \\
\text { (readers) }\end{array}$ & $\begin{array}{r}\text { Growth } \\
\text { (\%) }\end{array}$ \\
\hline National press published in Madrid & 3,336 & $4 ., 786$ & 1,450 & 43.5 \\
\hline National press published in Barcelona & 1,435 & 1,470 & 35 & 2.4 \\
\hline Regional and local press & 6,753 & 6,927 & 174 & 2.6 \\
\hline Sports press & 3,721 & 5,371 & 1,650 & 44.3 \\
\hline Financial press & 146 & 188 & 42 & 28.8 \\
\hline Free sheets & 221 & 5,987 & 5,766 & $2,609.0$ \\
\hline
\end{tabular}

Table 2: Readership of the top 50 newspapers (thousands of readers) ${ }^{6}$

However, increased readership has not meant increased sales (Table 3). National newspapers did increase their sales up to 2007, thanks to the emergence and upward trend of new titles. Meanwhile the older newspapers evolved in variable fashion: rising for La Vanguardia and, slightly, EI Pais; down for ABC and El Periodico. In the sports press, a growth in readership does not correspond to more sales. Instead, circulation decreased, mainly due to the poor performance of the

\footnotetext{
${ }^{6}$ Source: the author using data from EGM, 2009 http://www.aimc.es.
} 
leading title, Marca. But, undoubtedly, it has been the regional and local press which has suffered the greatest decline in circulation, although the Catalan press developed more positively.

\begin{tabular}{|l|r|r|r|c|}
\hline & 2001 & 2008 & $\begin{array}{c}\text { Growth } \\
\text { (copies) }\end{array}$ & $\begin{array}{c}\text { Growth } \\
\text { (\%) }\end{array}$ \\
\hline National press published in Madrid & $1,087,438$ & $1,229,195$ & 141,757 & 13.0 \\
\hline National press published in Barcelona & 375,924 & 353,884 & $-22,040$ & -5.9 \\
\hline Regional and local press & $1,711,985$ & $1,482,766$ & $-229,219$ & -13.4 \\
\hline Sports press & 787,307 & 743,671 & $-43,636$ & -5.5 \\
\hline Financial press & 104,965 & 239,406 & 134,441 & 128.1 \\
\hline Free sheets & 247,782 & $2,668,965$ & $2,421,183$ & 977.1 \\
\hline Total & $4,315,401$ & $6,717,887$ & $2,402,486$ & 55.7 \\
\hline Number of titles controlled & 93 & 106 & 13 & 14.0 \\
\hline
\end{tabular}

Table 3: Daily press circulation $2001-2008^{7}$

The largest increases therefore correspond to reading figures, and not sales, making press viability more dependent on advertising revenue. Since 2003, when sales of copies accounted for $46 \%$ of daily press income, the weight of circulation in the income structure fell to $38 \%$ in 2007 . Newspapers have tried to stem this loss of income and buyers by selling other products associated with the newspaper, which came to assume about $10 \%$ of revenue in 2005-2006. However, these promotions, which do not add informational value to the product itself, have proved ineffective for retaining or attracting new buyers, such that the policy of reducing costs has led to a reduction in its role and weight in income. It should also be noted that readership of newspapers increases in all age groups, even among the youngest, resisting competition from internet better than other traditional media (Figure 4).

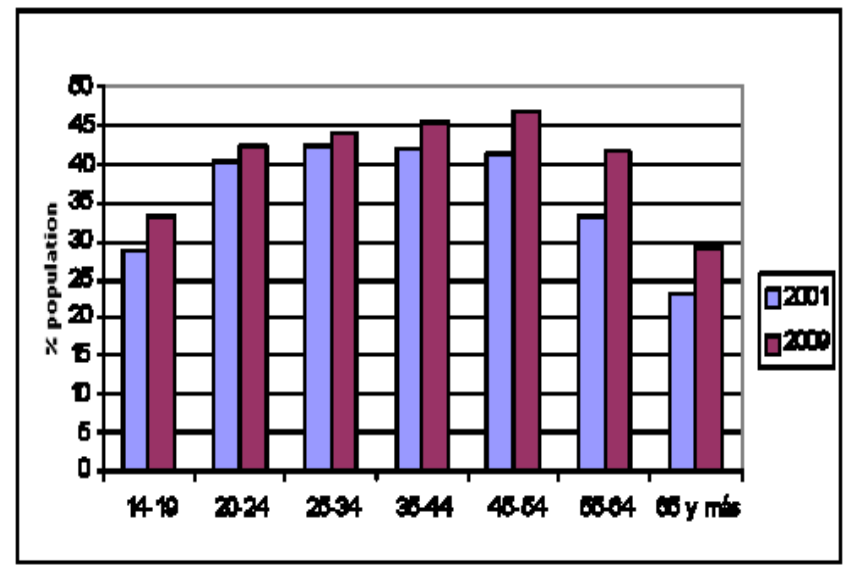

Figure 4: Daily press readers per day. Evolution by age, 2001-2009 (EGM, 2009)

The social penetration of radio improved three points over 2001 , reaching ratings of up to $58 \%$ of the population in 2004 . Although in recent years the rate has decreased to $55.2 \%$, the radio audience seems to have stabilized around that index. The greatest increase in audience, between 2001 and 2009, corresponds to music radio, earning 3.4 million listeners. All-news networks also gained audience, while growth has been lower for general interest radio (Table 4).

\footnotetext{
${ }^{7}$ Source: the author using data from OJD. http://www.ojd.es/
} 


\begin{tabular}{|c|c|c|c|c|}
\hline & 2001 & 2009 & Growth & $\begin{array}{c}\text { Growth } \\
(\%)\end{array}$ \\
\hline General interest & 10,804 & 11,136 & 332 & 3.1 \\
\hline Music & 7,703 & 11,136 & 3,433 & 44.6 \\
\hline All news & 935 & 1,329 & 394 & 42.1 \\
\hline
\end{tabular}

Table 4: Radio audience in Spain, 2001-2009 (thousand listeners) ${ }^{8}$

In this period, the evolution of audience share shows a concentration of listeners in the Prisa group networks (Ser, C40, Cadena Dial, Máxima FM). In general interest radio, Prisa-Ser increased its audience share, to $38 \%$. The remaining market is more fragmented (share between 4$17 \%$ for national networks, and less than $4 \%$ for regional ones), with increases for new networks and, to a lesser extent, for COPE. Public radio lost its audience share, both RNE, the national network, as well as some regional public networks.

The growing number of licences for commercial exploitation of FM has had a major impact on the musical spectrum, increasing the audience fragmentation which already characterized the musical radio market. Thus, despite gaining listeners, music networks operated by Prisa lost 10 points of their market share, although they still have an outstanding share of $58 \%$. The rest is divided between three national music networks, with audience shares of $8-10 \%$, and other networks (national and regional public and private networks), with market shares below $5 \%$. Thematic radio, meanwhile, has gained audience thanks to the increase in listeners to new private networks (sports and music, Intereconomía). In contrast, R5TD, an all news national public radio, has lost listeners.

Television has lost one point of its average daily audience in the last decade, but remains the most used media, with an average daily audience of $88.5 \%$ of the population. Despite this reduction, however, the average time devoted to television has risen to 227 minutes per person per day, five minutes more than in 2000 . That is, less people consume more television. TV consumption has declined especially among younger people, but also in other age groups (Figure 5).

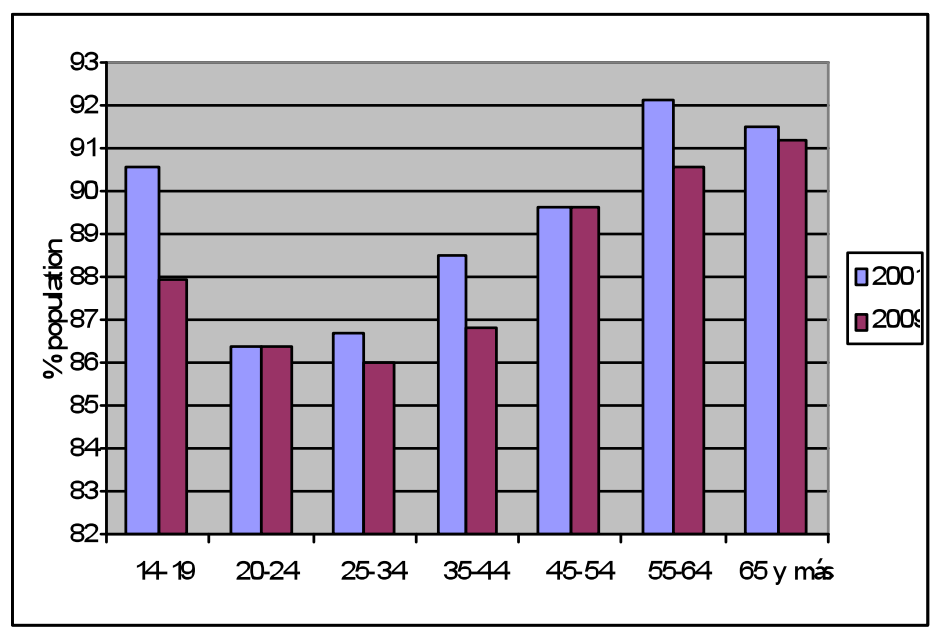

Figure 5: Television viewers per day. Evolution by age, 2001-2009 (EGM, 2009)

${ }^{8}$ Source: the author using data from EGM. 
Besides falling younger audiences, the major change in TV demand has been greater fragmentation, with pay-tv and new free-to-air channels created from 2005 gaining audience. Thus, audience share of the three traditional mainstream channels fell from $70 \%$ to $54.6 \%$ between 2001 and 2009 , although the free-to-air national channels as a whole have maintained and even exceeded their share (from 76 to $77 \%$ ). The regional public channels have a lower share, despite there being more channels, while pay TV gained audience.

\begin{tabular}{|l|c|c|c|}
\hline & 2001 & 2009 & $\begin{array}{c}\text { Growth } \\
\text { (share points) }\end{array}$ \\
\hline TVE+T5+A3 & 70.3 & 54.6 & -15.7 \\
\hline $\begin{array}{l}\text { All national free-to-air channels } \\
\text { (TVE+T5+A3+Cuatro+La Sexta) }\end{array}$ & 75.8 & 76.9 & 1.1 \\
\hline Regional and local channels & 18 & 17.1 & -0.9 \\
\hline Pay-tv & 2.7 & 4.8 & 2.1 \\
\hline Other channels & 3.2 & 1 & -2.2 \\
\hline
\end{tabular}

Table 5: TV audience in Spain, 2001-2009 ${ }^{9}$

\subsection{Results of media companies: crisis, but not as much, nor for all.}

The restructuring of media and advertising markets has had a different effect on the results of different types of companies in those markets. The crisis of 2008-2009 represents an abrupt change for many companies that have had years of profits, but arrived too late for many media companies that had already experienced their crises and that in the past two decades have had to close their doors or have been acquired by larger media groups.

Two groups stand out for their expansion into the daily press market, Prisa and Vocento. With different strategies, both groups have achieved a leading position in terms of audience, circulation, turnover and profits. Prisa's strategy was based on leadership of general news and its struggle for leadership in sports and the economy; Vocento's was based on the merger with $A B C$, in the national market, and its expansion into regional markets.

But in contrast to the success of these two groups, there have also been some failures among the titles launched in the last two decades: El Sol and El Observador only resisted for a few months before closing; El Mundo settled its place in the market, with positive results in the nineties but with more difficulties in the 2000s, when it was eventually integrated into the Italian media group RCS. More recently established journals, La Razón and Público, have presented negative results since they were launched, meaning 11 years of losses for La Razón.

Thus, the national press published in Madrid came into the crisis with positive results for El País, but was in the red for El Mundo, ABC, Público, La Razón, and also for the financial press. The regional and local press results are more diverse, both in recent years and in the past two decades. But the best figures are those for local titles integrated in large press groups. Prisa and Vocento each accounted for $24 \%$ of the turnover of the top ten press groups, and El País (Prisa) and Correo (Vocento) were the two companies with the highest net profit in 2007.

Economic results from the expansion and restructuring of the radio market have been different too. We should first note the prominent position occupied by networks controlled by Prisa, thanks to takeovers of smaller networks, syndication agreements with independent stations and expansion with new licenses. Prisa concentrated around $52 \%$ of sales and $65 \%$ of profit of the large Spanish radio networks in 2008. Prisa has achieved positive results in a growing radio business, which has

\footnotetext{
${ }^{9}$ Source: EGM, 2009
} 
been reinforced by the group's position in the Hispanic music market with radio stations and record companies in Spain and Latin America.

For the other actors, results have been more diverse, with all companies going through some period of losses, either due to their introduction in the market (Punto Radio), or to changes in markets and changes in ownership: COPE, the Church's network, announced losses for some years in the nineties; Onda Cero accumulated losses in the nineties and in 2000 , although positive results appear to have been consolidated since 2004, after Planeta was floated on the stock exchange.

In the case of radio, then, the crisis came after a major restructuring of the sector over the past 20 years, which has resulted in greater concentration in large media groups, in particular, in Prisa, added to the peculiar presence of the Church in the Spanish radio system. Smaller radio companies suffered a crisis in the eighties and nineties, and were mostly integrated into the large media groups. Only in the music sector were there a few independent networks with positive results (Kiss FM, with a national music network; Flaix and Teletaxi, in Catalonia).

Radio markets also illustrate the different evolution of informative media and that of entertainment/fiction media. The business of general interest radio is limited to fewer actors, and it is more difficult to achieve profit (in absolute terms and profit margin). Instead, music radio has performed better economically and admits a greater level of competition between players of varying size.

In the television market, free-to-air TV companies have accumulated positive results since 1994/1995, with just a year of net losses in Antena $3 T V$, because of the restructuring of its ownership, revision of valuation of content stocks and other extraordinary circumstances, while maintaining a positive operating margin in all years. Among the main channels, Telecinco presents itself as the most profitable TV channel in Europe. On the contrary, Cuatro (Prisa) and La Sexta (ImaginaTelevisa) have been introduced at losses, pushing for mergers: Cuatro was bought by Telecinco in 2010, and there are conversation for the merger of La Sexta in Antena 3TV.

Expanding the supply of pay- television with new technologies has resulted in losses, once the monopoly of Canal + in the pay-tv market was broken in 1996. Since then there has been:

- the merger, due to losses, of the two competing satellite pay-tv platforms, Sogecable and Via Digital;

- the collapse of Quiero TV, the pay DTT platform;

- concentration on cable television, with ONO (resulting from the acquisition of regional independent companies and the merger with Auna Cable);

- emergence of new IPTV, also with losses.

In pay-TV, Sogecable achieved a positive operating margin in 2002-2007, but net results have been negative since the launch of the payment platform, except in 2005. In terms of costs, the main reason for losses in pay-tv are the high prices paid for sports broadcasting rights and film rights, and changes in the market for broadcasting football. In late 2007, Sogecable accumulated losses up to 777 million Euros (Annual Accounts 2007). In terms of income, demand for pay-tv appears to have been an elastic demand, limited by the evolution in purchasing power, and increasingly fragmented between different technologies. Pay-TV, therefore, has to face the crisis in an unstable market, subject to technological, regulatory and business changes, and also in audiovisual consumption, which have further impeded the path of profit in this business. 


\begin{tabular}{|c|c|c|c|c|c|c|c|c|}
\hline & 2007 & 2006 & 2005 & 2004 & 2003 & 2002 & 2001 & 2000 \\
\hline EIPaís & $\begin{array}{r}73,902,00 \\
0\end{array}$ & $74,911,000$ & $\begin{array}{r}96,635,00 \\
0\end{array}$ & $83,974,000$ & $54,419,000$ & $\begin{array}{r}48,020,00 \\
0\end{array}$ & $\begin{array}{r}34,927,00 \\
0\end{array}$ & $\begin{array}{r}48,440,18 \\
0\end{array}$ \\
\hline El Mundo-Unidad Editorial & $-1,234,000$ & $32,450,000$ & $\begin{array}{r}26,577,00 \\
0\end{array}$ & $18,731,000$ & $2,533,000$ & $2,192,000$ & 896,000 & $8,966,000$ \\
\hline ABC & $12,484,964$ & $1,820,110$ & $5,769,612$ & $10,220,620$ & $2,294,450$ & 251,120 & $2,489,140$ & \\
\hline La Razón & $-4,031,725$ & $-249,074$ & $\begin{array}{r}- \\
5,375,772 \\
\end{array}$ & $-6,902,795$ & $-17,817,454$ & $23,054,002$ & $24,397,151$ & $18,479,130$ \\
\hline Público & $\begin{array}{r}- \\
12,402,225\end{array}$ & & & & & & & \\
\hline $\begin{array}{l}\text { National newspapers published in } \\
\text { Madrid }\end{array}$ & $\begin{array}{r}43,749,08 \\
6 \\
\end{array}$ & $\begin{array}{r}108,932,03 \\
6\end{array}$ & $\begin{array}{r}123,605,8 \\
40\end{array}$ & $106,022,825$ & $41,428,996$ & $\begin{array}{r}23,025,11 \\
8 \\
\end{array}$ & $\begin{array}{r}13,914,98 \\
9 \\
\end{array}$ & $\begin{array}{r}38,927,05 \\
0\end{array}$ \\
\hline La Vanguardia & $\begin{array}{r}12,626,59 \\
1\end{array}$ & $19,111,483$ & $\begin{array}{r}24,681,86 \\
0\end{array}$ & $23,555,494$ & $17,921,938$ & $7,714,309$ & $6,254,334$ & $\begin{array}{r}23,387,69 \\
0\end{array}$ \\
\hline Ediciones Primera Plana-El Periódico & $5,764,991$ & $4,452,757$ & $7,343,982$ & $13,426,209$ & $11,494,365$ & $9,512,613$ & $\begin{array}{r}10,529,77 \\
0 \\
\end{array}$ & $\begin{array}{r}15,086,36 \\
0\end{array}$ \\
\hline $\begin{array}{l}\text { National newspapers published in } \\
\text { Barcelona }\end{array}$ & $\begin{array}{r}18,391,58 \\
2 \\
\end{array}$ & $23,564,240$ & $\begin{array}{r}32,025,84 \\
2 \\
\end{array}$ & $36,981,703$ & $29,416,303$ & $\begin{array}{r}17,226,92 \\
2 \\
\end{array}$ & $\begin{array}{r}16,784,10 \\
4 \\
\end{array}$ & $\begin{array}{r}38,474,05 \\
0 \\
\end{array}$ \\
\hline As & $\begin{array}{r}11,021,00 \\
0 \\
\end{array}$ & $9,561,000$ & $7,625,000$ & $3,378,000$ & $3,782,000$ & $3,499,000$ & 488,000 & $2,124,920$ \\
\hline Mundo Deportivo & 802,453 & $1,920,654$ & $1,599,834$ & $1,767,309$ & $1,611,358$ & $1,165,426$ & $1,639,852$ & $1,061,410$ \\
\hline Sports press & $\begin{array}{r}11,823,45 \\
3 \\
\end{array}$ & $11,481,654$ & $9,224,834$ & $5,145,309$ & $5,393,358$ & $4,664,426$ & $2,127,852$ & $3,186,330$ \\
\hline Cinco Días & 592,000 & 209,000 & 169,000 & $-2,072,000$ & $-2,212,000$ & $\begin{array}{r}- \\
1,199,000\end{array}$ & $-946,000$ & $1,230,060$ \\
\hline Gaceta de los Negocios & $-8,399,675$ & $-5,870,490$ & $\begin{array}{r}- \\
5,050,465 \\
\end{array}$ & $-4,410,119$ & $-3,393,586$ & $\begin{array}{r}- \\
3,284,778 \\
\end{array}$ & $\begin{array}{r}- \\
2,597,727 \\
\end{array}$ & $1,566,260^{-}$ \\
\hline El Economista & $-6,659,714$ & $-2,021,247$ & $-6,929$ & & & & & \\
\hline Financial press & $14,467,389$ & $-7,682,737$ & \begin{tabular}{r|}
- \\
$4,888,394$
\end{tabular} & $-6,482,119$ & $-5,605,586$ & \begin{tabular}{r|}
- \\
$4,483,778$
\end{tabular} & \begin{tabular}{r|}
- \\
$3,543,727$
\end{tabular} & $-336,200$ \\
\hline Total press & $\begin{array}{r}59,496,73 \\
2\end{array}$ & $\begin{array}{r}136,295,19 \\
3\end{array}$ & $\begin{array}{r}159,968,1 \\
22\end{array}$ & $141,667,718$ & $70,633,071$ & $\begin{array}{r}40,432,68 \\
8\end{array}$ & $\begin{array}{r}29,283,21 \\
8\end{array}$ & $\begin{array}{r}80,251,23 \\
0\end{array}$ \\
\hline SER & $\begin{array}{r}44,903,00 \\
0\end{array}$ & $28,696,000$ & $\begin{array}{r}24,730,00 \\
0\end{array}$ & $18,965,000$ & $19,829,000$ & $\begin{array}{r}23,199,00 \\
0\end{array}$ & $\begin{array}{r}34,080,00 \\
0\end{array}$ & $\begin{array}{r}20,048,65 \\
0\end{array}$ \\
\hline Uniprex-Onda Cero & $24,979,00$ & $18,961,000$ & $13,325,00$ & $5,068,000$ & - & - & - & - \\
\hline
\end{tabular}




\begin{tabular}{|c|c|c|c|c|c|c|c|c|}
\hline & 0 & & 0 & & $155,665,000$ & $23,981,468$ & $12,342,568$ & $13,998,585$ \\
\hline COPE & $3,670,755$ & $4,421,884$ & $4,211,003$ & $3,807,739$ & 148,683 & $1,046,241$ & $2,744,163$ & $5,637,740$ \\
\hline Punto Radio & $-5,278,718$ & $-7,584,773$ & - & $-6,504,760$ & $-44,018$ & $-104,171$ & $-79,472$ & $-144,411$ \\
\hline Total radio & $\begin{array}{r}68,274,03 \\
7\end{array}$ & $44,494,111$ & $\begin{array}{r}38,399,91 \\
7\end{array}$ & $21,335,979$ & $135,731,335$ & 159,602 & $\begin{array}{r}24,402,12 \\
3\end{array}$ & $\begin{array}{r}11,543,39 \\
4\end{array}$ \\
\hline Telecinco & $\begin{array}{r}350,022,0 \\
00\end{array}$ & $\begin{array}{r}314,352,00 \\
0\end{array}$ & $\begin{array}{r}290,396,0 \\
00\end{array}$ & $203,973,000$ & $85,896,000$ & $\begin{array}{r}52,750,00 \\
0\end{array}$ & $\begin{array}{r}79,625,00 \\
0\end{array}$ & \\
\hline Antena 3 TV & $\begin{array}{r}200,033,0 \\
00\end{array}$ & $\begin{array}{r}289,717,00 \\
0\end{array}$ & $\begin{array}{r}226,010,0 \\
00\end{array}$ & $113,065,000$ & $206,929,000$ & - & $\begin{array}{r}48,004,97 \\
0\end{array}$ & $\begin{array}{r}123,310,5 \\
28\end{array}$ \\
\hline Sogecable & $\begin{array}{r}69,873,00 \\
0\end{array}$ & $-43,291,000$ & $8,143,000$ & - & $319,630,000^{-}$ & $54,240,000$ & $2,640,000$ & $14,708,000$ \\
\hline La Sexta & $\begin{array}{r}- \\
107,824,501\end{array}$ & $\begin{array}{r}- \\
138,491,969\end{array}$ & & & & & & \\
\hline Veo TV & $-6,845,890$ & $-9,208,121$ & $\begin{array}{r}- \\
1,779,634\end{array}$ & $-991,294$ & $-1,036,834$ & $-999,296$ & $-430,187$ & $-16,164$ \\
\hline Net TV & $-9,584,907$ & $-9,115,605$ & $\begin{array}{r}- \\
1,353,048\end{array}$ & $-1,847,154$ & $-2,401,217$ & $-745,684$ & -525 & -977 \\
\hline Total television & $\begin{array}{r}495,672,7 \\
02\end{array}$ & $\begin{array}{r}403,962,30 \\
5\end{array}$ & $\begin{array}{r}521,416,3 \\
18\end{array}$ & $153,135,552$ & 444,101,051 & $33,141,980$ & $\begin{array}{r}124,559,2 \\
58\end{array}$ & $\begin{array}{r}108,585,3 \\
87\end{array}$ \\
\hline
\end{tabular}

Table 6: Net results of the main media in Spain $(2000-2007)^{10}$

\begin{tabular}{|c|c|c|c|c|c|c|c|c|}
\hline & 2008 & 2007 & 2006 & 2005 & 2004 & 2003 & 2002 & 2001 \\
\hline PRISA & $126,400,000$ & $262,081,000$ & $230,327,000$ & $159,500,000$ & $104,948,000$ & $62,100,000$ & $79,292,000$ & $77,925,000$ \\
\hline VOCENTO & $30,365,000$ & 89526000 & $82,567,000$ & $114,200,000$ & $149,000,000$ & $183,264,173$ & $64,849,719$ & $33,486,036$ \\
\hline PLANETA & & & & & & & & \\
\hline RCS Group & $44,700,000$ & $234,900,000$ & & & & & & \\
\hline
\end{tabular}

Table 7: Net results of the main media groups in Spain $(2001-2008)^{11}$

${ }^{10}$ Source: the author using data from annual accounts available in Bureau van Dijk database.

${ }^{11}$ Source: the author using data from annual accounts available in corporate websites 


\subsection{Business models: increasing importance of external resources}

The expansion of the Spanish media industry over the past two decades has led to a shift in business models from "family" companies, with an integrated production in which funding was based on sales of copies and advertising, to multimedia groups, with a largely outsourced production model and more dependent on advertising revenue and external resources.

As noted, the expansion of the supply of media has occurred mainly in the field of free advertising-financed media: free newspapers, free-to-air private television, new radio frequencies, websites and social networks on the Internet. In terms of demand, the greatest growth has also occurred in advertising, while growth in sales to audience, readers or, pay-TV viewers, has been lower. Given the limits in demand for paid-contents by audiences, companies have pursued strategies to reduce costs, increase and diversify income and increase external resources.

To reduce costs, companies have adopted strategies of outsourcing parts of production and / or marketing, to reduce fixed costs of personnel and equipment, and gain flexibility to adapt to market changes. Outsourcing is higher in television, by the very nature of the business, but also affects the press, substituting part of the staff and its own equipment with purchases by external partners and agencies. It is noteworthy that, in the last decade, personnel costs have corresponded to a lower proportion of income, while material and services consumption and the profit margins of companies have increased.

However, outsourcing is sometimes not such, but is rather the decentralization of production among different companies and operating centres inside the same corporate group. As in the case of Sogecable or Telecinco, part of the production is outsourced, but to companies that are subsidiaries of the same business group. In this case, the group secures control of processes and supply, but at the same time, creates different societies and is able to act more flexibly in different markets to seek new sources of income. This is the case with Telecinco, which orders news production from its subsidiary, Atlas, which, at the same time, can sell news and images to other media, thus improving the profitability of investments.

Cost reduction has also come about through agreements and alliances between companies to achieve scale economies. These agreements involve limited competition and, in some cases, have ended in mergers or takeovers. In the press industry, agreements between companies for the printing and distribution of newspapers are common, such as the agreements between Vocento or Prisa with some local newspapers, which were eventually integrated into these groups. In local and regional television, it is also easy to find agreements for the acquisition of contents, which in many cases have led to the formation of networks, such as Localia TV, which disappeared in 2009, and Canal Català, among others.

Besides reducing costs, companies have sought to increase advertising revenue by bringing out new products and diversifying production to be in any media. Thus, the companies operating in the pay-press market (Vocento, Planeta, Zeta, regional publishers) have used their production equipment to create free sheets, and to protect and expand their advertising portfolio against competition from new multinational players. Moreover, the growth of mass media companies in Spain is based on their expansion into the audiovisual business, where most of the advertising expenditure is directed.

Furthermore, given the limits on cost reduction and increase in revenues, companies have sought external resources to complete their financing. In this way, they have benefited from the liberalisation of financial markets and the relaxation of limits on the concentration of ownership and other rules on the capital stock of TV companies. The growth in external resources corresponds both to capital increases and a growing debt.

In the nineties, the launch, with losses, of private television enjoyed the financial support of the major European media groups and Spanish banks. Later, satellite and cable pay-tv platforms benefited from financial resources from banks and investment firms, multinational companies and companies from other activities (electricity, tobacco, construction), which took part of the capital of 
the platforms. The free sheets in big cities was introduced with financial support from international investment funds, shareholders of Metro International and Schibsted-20 minutes.

Intra-group financing should also be considered in this category, where the profits of an activity are intended to be used to finance the group's expansion into other activities. This applies to the expansion of local television markets, where Prisa and Vocento could earmark a portion of the profits generated by their news divisions to finance local channels, especially in those markets where they were already present. Also small press publishers took advantage of the resources generated by the press and its advertiser's portfolio to expand their activities to the audiovisual market, enduring several years of losses. The Planeta-deAgostini group disposed of the resources generated in the publishing business to expand its activities into TV, and to finance the loss-making introduction of the daily La Razon. Media corporations also opted to make their companies public to attract more financial resources from the stock market and improve profitability for large shareholders. In early 2000, Prisa and Sogecable, Telecinco, and Antena 3 TV went public.

Finally, we should note the increasing debt of media groups. In the nineties, the expansion of private television involved banks, not only as shareholders, but also as creditors, allowing high levels of debt, up to $11 \%$ for Telecinco in 1994 (measured by assets/equity). Later, the expansion of large groups and the emergence of new products also heavily relied on borrowing, taking advantage of the close relationship between media groups and financial institutions. We could highlight the case of Prisa, who, in 2008, reached a debt ratio of $6.4 \%$ (assets / equity). In many cases, the companies chose indebtedness to improve capital efficiency thanks to financial leveraging.

\begin{tabular}{|c|c|c|c|c|}
\hline & & Prisa & Antena 3 TV & Vocento \\
\hline \multirow{4}{*}{ Debt (assets/equity) } & 2001 & 2.5 & 1.5 & no data \\
& 2002 & 2.4 & 2.0 & no data \\
& 2003 & 2.5 & 3.5 & no data \\
& 2008 & 4.8 & 2.8 & 1.9 \\
& 2001 & 26.1 & 3.3 & 1.9 \\
\hline \multirow{4}{*}{ Labour costs } & 2002 & 26.7 & 22.2 & no data \\
& 2003 & 25.2 & 22.9 & no data \\
& 2007 & 16.9 & 13.5 & 30.7 \\
& 2008 & 16.7 & 16.2 & 37.2 \\
\hline \multirow{5}{*}{ Profit margin } & 2001 & 6.5 & 8.3 & no data \\
& 2002 & 6.5 & -4.7 & no data \\
& 2003 & 4.8 & -32.7 & no data \\
& 2007 & 7.1 & 19.7 & 9.8 \\
& 2008 & 3.2 & 10.9 & 3.6 \\
\hline
\end{tabular}

Table 7: debt, personnel costs and profit margin in the main media groups in Spain ${ }^{12}$

${ }^{12}$ Source: the author using data from annual accounts available in corporate websites 


\section{Crisis of journalism: from general interest to economic interest}

Changes in the political-economic context and in media markets and industries have obviously affected the forms of making journalism, and the very situation of journalism in the communication system and in the social system. Some of the main protagonists of the Information Society or globalisation projects are at the core of the media framework, either as shareholders and directors, creditors or other external lenders or advertisers. Changes in advertising markets and audience markets put pressure on the definition of products (that is, in the definition of content offered by media) to make them increasingly attentive to market research. Expenditure on production is optimized for maximum productivity with content able to attract audiences and advertising. The marketing, production and financing strategies of media companies should be considered, then, as to be new strains of the journalism model in the Information Society.

For years, information and even entertainment through media were considered (and in some cases, apparently, still are) a public service due to their capacity to legitimize, reinforce and reproduce the political, economic and social values of the system. The situation changed with the liberalization of television, which strengthened economic arguments in managing the media. In this context of commodification of communication and journalism, the oversupply of content makes it more difficult for firms to compete in communication markets. This involves finding new ways of reaching bigger audiences and reducing costs in order to make investments profitable, even at the expense of trivializing and diminishing the quality of the product.

So media have been losing their social function, and have become more concerned with achieving the maximum profits and a share of political and economic power, as described by McChesney (2003). For example, due to their political and economic interests, dailies do not give (except occasionally) quality differential information, or have independent information.

\subsection{Lack of independence}

Economic trends and social policies in recent years have led almost all media to a greater or lesser degree of dependence. Three types of lack of independence should be mentioned that condition much of the content they offer: financial, political and journalist' lack of independence.

On the one hand, cuts in corporate budgets and a large range of workforce in journalism have been associated with a high level of job insecurity. Along with the growing tendency to report as quickly as possible, that job insecurity has made journalists hugely dependent on information coming from official sources and what is commonly termed as statement journalism.

Every day, thousands of stories from news agencies, communication departments of private companies and public institutions come to the newsrooms. This information is a raw material that lowers the cost of media companies which is justified by considering this form of journalism more "objective." But, in fact, this journalism made up of press releases and statements has come to determine the agenda-setting of the media: official sources determine around $70 \%$ of the news published in the media, and there is an increasing number of journalists working for the sources, in communication offices and corporate communication departments. Little margin remains, then, for the selection, criticism and contrast of information or investigation by journalists due to the limited time and resources they have at their disposal.

A part of "agenda" journalism, one cannot ignore what could be dubbed "failure by commitment." The media's dependence on funding sources has led them to go on tiptoe, or just not mention, information that may damage the image of important advertisers, sponsors and financial institutions that provide them with resources. The shareholders of many groups and media companies include companies in other sectors that were favoured by the neoliberal policies of the $90 \mathrm{~s}$ and diversified their activities by investing in media companies. In addition, as has been pointed out, heavily indebted media companies also depend on credit institutions. 
This explains the lack of independence on economic grounds that the sector suffers: How can the media report on the current crises or conflicts involving a particular bank if its economic and financial viability depends on it? Therefore, it has been hard to find quality articles and in-depth analysis of a financial system that, with the crisis, has come across as a naked king being fed by the media. While financial institutions covered capital needs for the expansion of large media companies, these media groups repaid them by covering their communication needs, as discussed by Almirón for the case of Prisa-Santander (Almiron, 2007). For example, the court cases against Banco Santander and its chairman, Emilio Botín, went unnoticed in a country that fills its talk-shows with court cases, but which are related to accidents, crimes and reality TV. Neither are the problems with excess liquidity and solvency of many financial institutions in the current crisis mentioned; nor is there much comment on the difficult situation of many construction and real estate companies which in recent years have supported many local media and, in some cases, large groups too.

The third level is enterprises' lack of political independence. Communication policies in Spain are characterized by fragmented legislation, sometimes improvised according to the politicaleconomic situation of the moment, and easily changeable. Popular Party governments resorted to the laws accompanying the budget to reduce restrictions on the concentration of ownership in television and to regulate the implementation of Digital Terrestrial Television, setting up a payment model that collapsed shortly after (Quiero TV). Years later, in 2005, the PSOE government passed a law in defence of pluralism (Ley 10/2005, dated 14 June, on Urgent Measures for the Promotion of Terrestrial Digital Television, the Liberalization of Cable and Development of Pluralism), which enabled the introduction of two new analogue free-to-air channels, La Sexta and Cuatro (the latter substituting Canal +, a payment channel which has become obsolete due to the growing supply of payment platforms). That political decision facilitated the market position of both companies in view of the large increase in supply planned for a few years later, with the analogue switch-off and final introduction of DTT.

In 2009, four years later, and in view of the crisis in media industries, two new decrees have been approved, authorizing mergers between operators (Royal Decree-Law 1 / 2009, dated 23 February, on urgent measures concerning telecommunications) and re-authorizing a model of paytv in DTT (Royal Decree Law 11/2009 of 13 August, which regulates, for licenses at the state level, the provision of payment- digital terrestrial television with conditional access). From the urgent measures to promote pluralism the government has shifted towards emergency measures to allow concentration; from measures to facilitate the growth of free-to-air TV it has switched to the authorization of a model of pay-DTT, opening the door for the Mediapro group, which was willing to exploit its rights to football through pay-tv, with Gol TV.

The connection between the political system and the media system can also be seen at the regional level. There are certain correlations between the party ruling in regional governments and the results of the tenders for regional and local DTT licenses (de Mateo, Bergés, 2009); and business cycles in private television are correlated with election cycles (Bergés, 2004). Similarly, some of the newer regional public channels commission content production and advertising sales to private media companies, increasing their dependence on political decisions. All these political decisions determine the practice of journalism and business strategies to compete in a rapidly changing industry that is moving in different directions, depending on which party is ruling.

\subsection{Trivialization and emotions to cut costs and gain audience}

In times of falls in advertising and sales, the media are focusing their goals on reducing costs and increasing audiences, often at the expense of the quality of the end product. "Serious" information for mass audiences is no longer profitable enough (but is for a smaller public willing to pay), and therefore, journalism tends to trivialization. An example: the worldwide media (400 accredited journalists) attended the presentation of Real Madrid player, Cristiano Ronaldo. This is information that does not cost much money or effort but which generates high interests on the part of audiences, advertisers and media companies themselves, as they can monetize this investment 
in other ways. For such information there are resources. Instead, it is more difficult to find money for investigative reporting of political or economic cases that are of social interest for democratic accountability. Cost reduction strategies also limit the geographic coverage of newsrooms, which become more dependent on official sources and main news agencies.

In recent years, local information, sensationalist reporting of events (and the pseudo-events of reality television) have gained ground on international, analytical and critical information. On mainstream channels, morning and afternoon magazines have replaced political and economic debate and information with talk-shows in which the loudest voice is the one that is heard the most.

\subsection{Precarious employment, precarious journalism}

Many media firms have not used the years of high profit to redefine the business model and consolidate their companies in order to ride out the current crisis with better safeguards. Now, immersed in the crisis, both of audiences and advertising expenditure, they tend to seek quick solutions to balance their income statements. The outsourcing of parts of the production process gives them more flexibility and less costs and allows them to avoid collective agreements. In the newsrooms, that means substituting staff journalists with collaborators and freelance journalists.

Economic interest takes priority over informative interest in many cases and, therefore, companies that still make profits (although lower) opt to downsize under the justification of being more competitive. These decisions seem to be more socially acceptable and easier to justify in moments of crisis in all economic sectors. Some examples: El Periódico (Grupo ZETA), has agreed with the unions to fire over 400 of its staff of 2,300; or the persistent rumour of a potential dismissal program in the Grupo Prisa, very much influenced by the latest bad results of the group.

\begin{tabular}{|c|c|c|}
\hline & Company & Dismisals \\
\hline \multirow[t]{2}{*}{ Grup Godó } & La Vanguardia & $\begin{array}{l}\text { Administration } \\
20+60 \text { (compensated leaves in pre- } \\
\text { print department and newsroom) }\end{array}$ \\
\hline & $\begin{array}{r}\text { Prisma } \\
\text { Publicacions }\end{array}$ & 14 \\
\hline \multirow[t]{3}{*}{ Grupo Prisa } & El País & 83 (compensated leaves) \\
\hline & Localia TV & 300 \\
\hline & Prisa Com & s.d. \\
\hline Grupo Z & Grupo Z & 442 \\
\hline \multirow[t]{2}{*}{ Vocento } & $A b c$ & 238 \\
\hline & Qué & 131 \\
\hline Schibsted & 20 minutos & 55 \\
\hline Planeta & ADN & 16 \\
\hline Metro Internacional & Metro España & 83 (closed) \\
\hline RBA & magazines & 15 \\
\hline Telemadrid & & 123 \\
\hline La Gaceta de los Negocios & & 67 \\
\hline El Mundo de Almería & & 18 \\
\hline Diari de Sabadell & & 7 \\
\hline Diari de Terrassa & & 4 \\
\hline Diario de Almería & & 8 \\
\hline Gente de Madrid & & 8 \\
\hline Regió 7 & & 7 \\
\hline $\begin{array}{l}\text { Total dismissed journalists: } \\
2008 \text { / January-April } 2009\end{array}$ & & 3,500 \\
\hline
\end{tabular}

Table 8: dismissals in Spanish media $(2008)^{13}$

${ }^{13}$ Source: Fabian Nevado, 2009 "Situación del sector medios de comunicación", presented at the conference of the Association of Journalists of Catalonia, in April 2009. 
The most common and perhaps less traumatic way of undertaking some of the layoffs is by DNI, meaning early retirement incentives in the companies. This implies losing the most experienced and the most expensive productive structure, and filling those vacancies with less and younger staff and, in most cases, external work. Many of these "early retirees" have been mainstays in their respective media and, in turn, the references and sources of credibility and information for many people. Some experts have dared to qualify early retirement as the worst of solutions, taking into account labour market efficiency and final product quality.

The latest staff restructures in the media have meant, in many cases, less human capital, with more freelance workers and collaborators, who do the same work or more. They enter a dangerous spiral where the journalistic content impoverishes as the media dispense of more experienced professionals. Furthermore, the use of external partners reduces pluralism and quality of information because, often, the same freelance or external company will be offering the same or similar content to different media, to make better profits out of low-paid work.

Reducing the number of journalists doing the same amount of work, results, in many cases, in so called "table journalism". Increasingly, many news reports in newspapers are the result of "cut and paste" information from news agencies or media offices, which spend much more time and resources in preparing the text that best meets their expectations. Thus journalism loses the critical capacity and the verifying dimension that is supposed to characterize this profession.

It cannot be forgotten that the journalistic profession has also entered the tunnel of uncertainty. Added to dismissals, vast amounts of journalism graduates enter the labour market each year. In 2008 , the number of journalists exceeded 69,000 people, while the market could only provide work for less than half. This oversupply of labour for fewer jobs increases the precariousness of the sector.

\subsection{Watchdog: what do the media guard?}

The social function of journalism as a watchdog, as a mechanism for the control of power, as the guardian of the right to information and freedom of expression as essential ingredients of democracy, lost strength in the new scenario of the Information Society and with the dynamics discussed in the media industry. Instead, media and journalism inside these groups act as the watchdog or guardian of the interests of power, of corporate interests.

Journalism is losing that ability to control, where it was considered the fourth power in a democracy. On the one hand are the servitudes of the lack of independence of media companies, precarious employment in journalism and the very logic of profit-making applied to journalistic production. On the other hand is a change in the position of journalism in the public space, from a scenario in which newspapers and journalism occupied a central space among the media, to a scenario of global competition in communication markets: the supply of different contents is multiplied, and journalism has to compete for audiences and advertising with entertainment, sports or fiction; new companies are appearing that make content available for users through new technologies, where public or mass communication mixes with group and personal communications; there is a restructuring of the audience share of different media and different content; and the media markets become international. The crises of journalism in this scenario have many parallelism with the situation described by McChesney for the United States (McChesney, 2010).

The ability to explain the reality, the role of control and criticism of abuses of power, guaranteeing the right to information, is transferred in part to citizenship, through so-called citizen journalism or through civic organizations engaged in reporting on their areas of interest, with observatories, online documentation centres, digital community media and other online tools or applications. Internet and new technologies have also created the proliferation of blogs and spaces in the network where anyone can contribute their vision of reality, talk about it and rank information from their point of view. According to The State of the Blogosphere, in 2007, there were 133 million online blogs. Although only $1 \%$ are updated weekly, many of them build small loyal audiences and 
establish an almost personal relation: the audience can participate, give opinions, and create virtual mini-communities.

The development of these forms of public information, citizen journalism and different kinds of community media can sometimes promote demagoguery, rumour and lies, when they do not simply feed events-journalism, as seen in the increased use by media companies of user-generated content on news of accidents and natural disasters. In others, they can pick up the baton of critical reporting that the traditional media are losing. It is such citizen journalism that allowed people to receive alternative information on the Iraq war and that openly detailed the military and industrial interests of many of the major world powers.

\section{New business models: new journalism or journalism for the elites?}

Given the situation of crisis (of overproduction, of sales to audiences and advertisers, of financing, of results, of journalism) companies that see a profit in such troubles are demanding that the sector's business model should be rethought. Companies are seeking new ways of advertising and obtaining more revenue by selling content to the user, with the recurrent discussion of whether the public should pay to access the online press.

A study by the Times showed that $40 \%$ of people are informed by the Internet as opposed to $35 \%$ who buy newspapers. The amount of Internet users is growing, but it is an audience that is used to the internet being free. In principle, economic theory states that you have to pay for scarce goods. But in terms of online information, this is anything but scarce. It certainly isn't, but would the users be willing to pay for quality information? For a genuinely scarce and useful product? In that sense, companies are seeking for new forms of payment that best suit the interests of consumers, such as paying for downloadable content, or subscriptions to personalized information packages. However, pay per download, a model that is being increasingly adopted by music and film commercialisation, is not so well applied to the business of informing large audiences, because of the frequency of transactions, unpredictability, and diversity of interests. In contrast, user payment is an important source of revenue for companies that offer high added-value information, such as scientific, economic and legal information, and who find their customers mainly in the business world.

Thus, in the information societies one can find a model, already raised in 1988 by Robbins and Webster, with three levels according to the type of information, its distribution and consumption. In a first level, there is no segmentation of the market. Format and content are not adapted to the different interests or needs of the audience, rather a standard product is provided that seeks to attract as much audience as possible. Most of the mass media can be included in this group. General interest channels have this goal: to reach the highest audience even at the expense of content. The new Digital Terrestrial Television has introduced more channels, which should enable greater specialization. But the lack of economic resources and profitable ideas means, for the moment, that more choice does not translate into higher added value.

Secondly, there are payment platforms (TV or online services). These offer almost- exclusive content (such as certain sporting events), or quality content (premiere films, quality documentaries), for which the consumer is willing to pay. This being so, it is still content aimed at large audiences, just that it is segmented depending on who can afford it or not.

And finally, a third level of journalism includes those media that provide information not for free but that is specialized, well documented and very valuable to their audience. They offer financial, scientific and business information with high added value. They are aimed at a public that is "interested" and willing to pay large sums of money for very specific information, which they will use for decision making or to monetize their own businesses. This can be seen in the evolution of Reuters, after its merger with the Canadian news, database and specialized information company, Thompson. The new Thomson Reuters employs 50,000 workers, of whom only 2,500 are in the news department aimed at mass media, while the bulk of the company is dedicated to "intelligent information for businesses and professionals", as their slogan states. 
In this situation, media companies that target broad audiences show little interest in finding new content, or in improving product quality to suit the needs of new users. The media's battle to survive in this market should involve differentiation and the quality of editorial content. But in Spain, unlike most European countries, all newspapers are directed at a single reader profile, without any large market differentiation (quality, middle-class, popular). This conditions them, and means they face tougher competition because they all share the same market.

Meanwhile, the proliferation of new media, new communication channels (blogs, micro blogs, citizen journalism ...); and of much more supply, forces them to offer a product with higher added value. This challenge is hardly feasible for the media that target the mass audience, for whom economic performance is the focus, but is much closer to the specialized companies that seek to offer credibility and confidence to a much smaller audience.

Given these limitations on sales of information to the final consumer, both in traditional and online media, media companies and independent journalists are seeking new funding resources by appealing to the general interest. Voices calling for public funds to compensate for the general interest service that these companies would be providing by offering quality journalism are increasing. Companies are also asking for non-profit private funding, donations from members and third parties, and appealing to the interest of sustaining the production of quality journalism.

\section{Conclusions}

Following the industrial, monetary and oil crisis in the early seventies, a process of political and economic transformations began to ensure constant economic growth, obviating the scarcity of resources. These transformations resulted in a new model of economic growth and exchange, mainly based on the service sector, which has been called the Information Society.

This model is based on the principles of liberalisation, deregulation, privatisation and international competitiveness, which have been applied to the development of the communication industry, seen as an activity of economic interest rather than an activity of general interest for democratic societies. This has had an impact on journalism, which has lost independence and whose quality is becoming more dependent on the user's capability to pay. Thus, journalism for large audiences deals with increasingly trivial topics, and is becoming more precarious given the employment situation of most journalists. Meanwhile, information of higher quality and higher added-value (scientific, legal and business, among others), is reserved for payment services available to social groups with greater buying power.

As the crisis in the Information Society, begun in 2007, the media and journalism crisis seems to be a structural rather than cyclical one. However, the solutions adopted so far, such as debt, outsourcing, the reduction of costs, and finding new sources of revenue, are designed to maintain growth without limits in the supply of media - growth that, like the unlimited growth of the economy, has been shown to be untenable.

\section{References}

Almirón, N. (2006). Poder financiero y poder mediático: banca y grupos de comunicación. Los casos del SCH y PRISA (1976-2004). Retrieved January 20, 2010, from http://www.tdx.cat/TDX-1220106-102823

Amoedo, A. (2008). Redefining Regional Public Radio in Spain: Challenges of the Public Radio of the Autonomous Regions. Proceedings of the Ripe Conference, 2008, Participation+Partnership . Retrieved January 20, 2010, from http://www.uta.fi/jour/ripe/2008/papers/Amoedo.pdf

Arriola J. \& Guerrero, D. (eds.). (2000). La nueva economía política de la globalización. Bilbao: Universidad del País Vasco.

Bellamy Foster, J. \& Magdoff, F. (2009). La gran crisis financiera: Causas y consecuencias. México: Fondo de Cultura Económica.

Bergés, L. (2004). Anàlisi econòmica i financera de TVE, Antena 3 TV, Telecinco i Canal Plus i del seu entorn (1990-2000): la mercantilització de la televisió espanyola. Retrieved January 20, 2010, from http://www.tesisenxarxa.net/TDX0726105-231600/

Bergés, L. et altri (2008). El mercat publicitari a Catalunya i el finançament dels mitjans de comunicació. Bellaterra: IncomUAB (mechanographed). 
Buró Van Dijk (February 2010). SABI: company information in an instant. Retrieved February 7, 2010, from http://www.bvdep.com/en/SABI.html.

CPII (1983). Économie mondiale: la montée des tensions. Paris :Economica.

CPII (1984). Économie mondiale, 1980-1990 : la fracture ?. Paris: Economica.

EC (1994). Europa y la sociedad global de la información (Bangemann Report). EC: Brussels.

Guimerá, J.A. (2006). La televisió local a Catalunya: gestació, naixement i transformacions (1976-2005). Retrieved January 20, 2010, from http://www.tesisenxarxa.net/TDX-0307107-151707/index_cs.html

Harvey, D. (2005). A brief History of neoliberalism. New York: Oxford University Press.

Infoadex (2009). Estudio Infoadex de la inversión publicitaria en España 2008. Madrid: Infoadex.

Infoadex (2009). Infoadex Informa, n. 36, 16/04/2009. Madrid: Infoadex.

Mateo, R. de (2006). Dinámicas empresariales y mercados de la comunicación" In X. López \& R. Aneiros (coords.). Comunicación e Cultura en Galicia e Portugal (pp.11-39). Santiago de Compostela: Consello da Cultura Galega, sección de Comunicación.

Mateo, R. de, \& Bergés, L. (2009). Los retos de la televisión pública: financiación, servicio público y libre mercado. Sevilla/Zamora: Comunicación Social.

McChesney, R. (2003). The media crises of our times. Project censored. Retrieved June 23, 2008, from http://www.thirdworldtraveler.com/McChesney/Media_Crisis_Times.html.

McChesney, R. (2010). The Death and Life of American Journalism. Philadelphia, Pa.: Nation Books.

Nevado, F. (2009). Situación del sector medios de comunicación. Proceedings of Jornadas del Col/legi de Periodistas de Catalunya, April 2009. Retrieved January 20, 2010, from http://sindicat.org/spc/docum/uploads/CJ_VI_Congres_Informe_Sector.pdf

Observatorio Europeo del Audiovisual (2009). Yearbook online premium service 2008. Retrieved November 24, 2009, from http://www.obs.coe.int/yb_premium/public/.

Robins, K. \& Webster, F. (1988). Cybernetic Capitalism: Information, Technology, Everyday Life. In: V. Mosco \& J. Wasco (ed). The Political Economy of Information (pp.76-94). Wisconsin: University of Wisconsin Press.

WARC (2009). News, Ideas and evidence for marketing people. London: Warc. Retrieved December, 20, 2009, from http://www.warc.com/

WARC (2010). News, Ideas and evidence for marketing people. London: Warc. Retrieved March, 25, 2010, from http://www.warc.com/

\section{About the Authors}

Rosario de Mateo

Professor of Theory, History and Structure of Communication, Department of Media, Communication and Culture, Autonomous University of Barcelona (AUB). Teaches "Media projects and management" at the Faculty of Communication Sciences, AUB. Member of the Euromedia Research Group.

Laura Bergés

Post-doctoral researcher on Media economics and policies, Department of Media, Communication and Culture, Autonomous University of Barcelona. MBA in Financial Information by the AUB and the College of Journalists of Catalonia. Teaches "Media projects and management" at the Faculty of Communication Sciences AUB. Member of the Euromedia Research Group. Collaborator with the Catalonia Broadcasting Council.

Anna Garnatxe

Assistant professor, Department of Media, Communication and Culture, Autonomous University of Barcelona. Teaches "Media projects and management" at the Faculty of Communication Sciences AUB. News editor at Televisió de Catalunya. MBA specialised in mass media communication companies, Universitat Pompeu Fabra. 